\title{
The larva and pupa of Cochliopsyche vazquezae (Trichoptera:Helicopsychidae)
}

\author{
MARgot P. Monson and RALPH W. Holzenthal ${ }^{1}$ \\ Department of Entomology, University of Minnesota, \\ St. Paul, Minnesota 55108 USA \\ GILBERT G. AHLSTRAND \\ Department of Plant Pathology, University of Minnesota, \\ St. Paul, Minnesota 55108 USA
}

\begin{abstract}
The larva and pupa of Cochliopsyche vazquezae Flint are described, representing the first complete description of these stages for the genus. The larva is characterized by the possession of a prominent patch of setae on the anterolateral margin of the head capsule and by a marked concavity in the postgenal region, giving a "hollowed out" appearance to the posterolateral aspect of the head. Pupae bear a similar group of setae below and mesad of the eye. Notes on the biology and habitat of C. vazquezae in Costa Rica are given.

Key words: Cochliopsyche vazquezae, Helicopsychidae, larva, pupa, biology, phylogeny, Neotropics, Costa Rica.
\end{abstract}

The family Helicopsychidae, especially the species Helicopsyche borealis (Hagen), is one of the best known and most easily recognized groups of North American caddisflies. Few benthologists may be aware, though, of the species diversity and distribution of other members of the family. Of the three currently recognized helicopsychid genera, Helicopsyche von Siebold is by far the most diverse and widely distributed. Most of its almost 100 species occur in tropical regions around the world and new species are discovered frequently in collections. The immatures of Helicopsyche have been described a number of times, e.g., Betten (1934), Botosaneanu and Sykora (1973), Flint (1968), and Wiggins (1977), among others. The biology of Helicopsyche borealis is well known in comparison with other species in the family (Resh et al. 1984, Vaughn 1985, 1987, Williams et al. 1983). The genus Rakiura McFarlane, with its single species $R$. vernale, is endemic to New Zealand. Cowley (1978) described the immatures of $R a-$ kiura vernale, and Michaelis (1973) discussed its life history. Cochliopsyche is known only from the Neotropics and contains four described species: C. clara (Ulmer, 1905) (as Tetanonema clarum), C. opalescens Flint, 1972, C. lobata Flint, 1983, and C. vazquezae Flint, 1985. Of the three genera, only the immatures of Cochliopsyche re-

\footnotetext{
${ }^{1}$ To whom correspondence should be addressed.
}

mained unknown before now. Müller (1921, fig. 186d) illustrated the pupal abdomen of a Cochliopsyche species, probably C. clara, from Brazil. However, the larva and case of Cochliopsyche have remained unassociated and undescribed.

The placement of other genera listed by Fischer (1970) under Helicopsychidae has changed. Ceylanopsyche Fischer (=Noleca Mosely), originally placed in Sericostomatidae, was provisionally transferred to Helicopsychidae by Schmid (1958). Malicky (1973), upon discovery of the immature stages, concluded that Ceylanopsyche should be included again in Sericostomatidae. The genus Saetotricha Brauer was recently synonymized with Helicopsyche (Neboiss 1986).

The descriptions of Cochliopsyche immatures provided in the present paper, along with those previously published of Helicopsyche and Rakiura, should greatly facilitate studies in comparative morphology, ecology, behavior, evolution, and biogeography of this most interesting family of Trichoptera.

\section{Methods}

Larvae were positively identified as Cochliopsyche vazquezae by the metamorphotype method (Milne 1938). Larvae and pupae were preserved in the field in Kahle's fluid and later transferred to $80 \%$ ethanol in distilled water for 


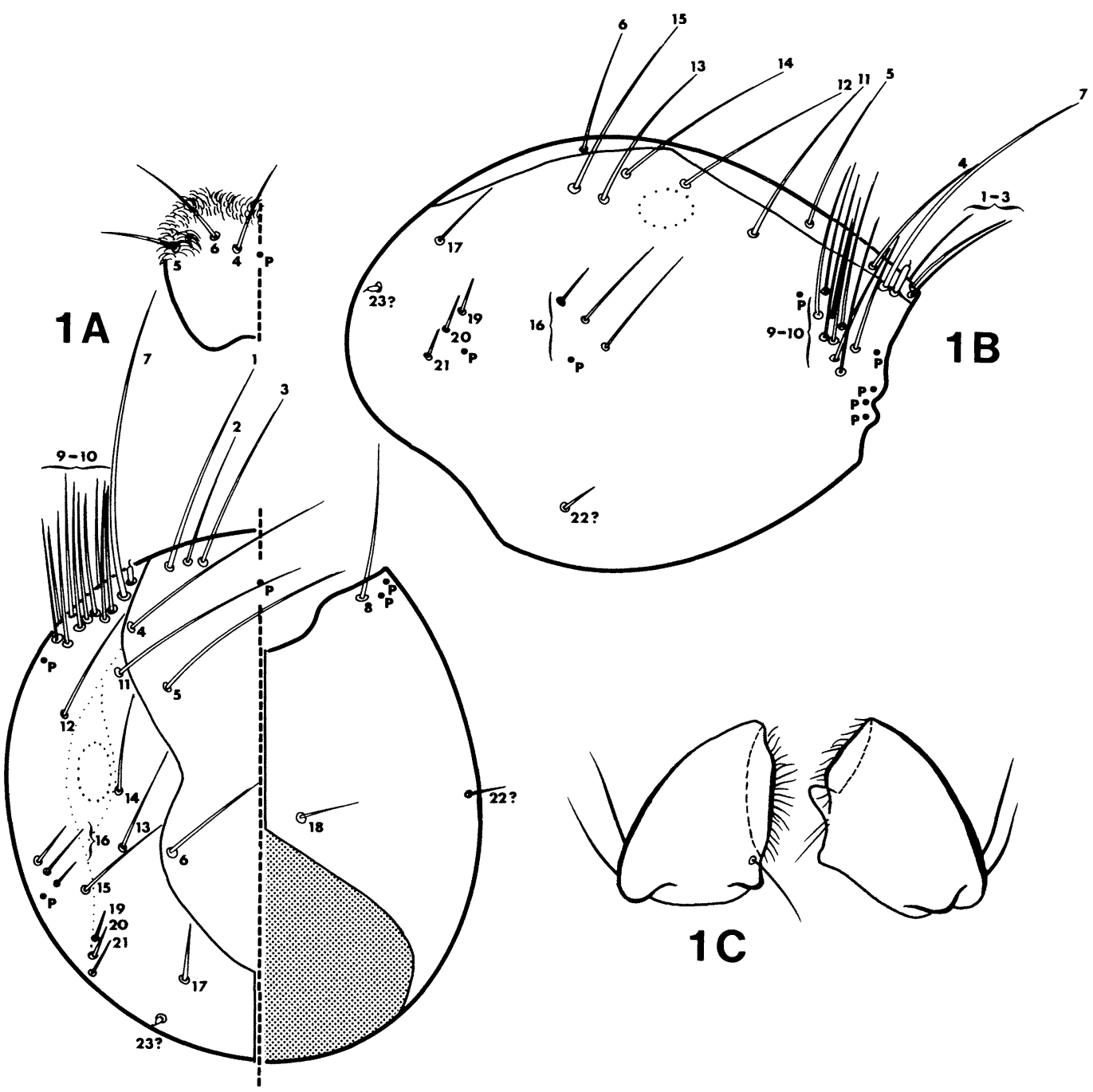

Fig. 1. Cochliopsyche vazquezae Flint, larva: A.- head and labrum setal pattern (labrum detached), left half dorsal, right half ventral; B.- - head setal pattern, right lateral; C.--mandibles, ventral.

storage. Larvae and pupae were removed from their cases and examined (with magnification up to $195 \times$ using an Olympus SZH dissecting microscope) and illustrated. For setal examination, several head capsules were removed and placed for $24 \mathrm{hr}$ in cold $10 \% \mathrm{KOH}$ for clearing. Head capsules were then rinsed in distilled water and suspended in glycerin in a U.S.B.P.I. watch glass. They were examined (with magnification up to $400 \times$ under an Olympus BH-2 compound microscope) and illustrated. Setal nomenclature follows that of Wiggins (1977) and Williams and Wiggins (1981).
A larval head capsule and case were also examined with a scanning electron microscope (SEM). Head capsules were dehydrated in three changes of absolute ethanol (20 min each), transferred to perforated metal baskets lined with filter paper under absolute ethanol, and dried in a Ladd critical point dryer using $\mathrm{CO}_{2}$ as the working fluid. A dot of colloidal graphite paste on the head of a dissecting pin (trimmed to $0.5 \mathrm{~cm}$ length) was used to pick up a head capsule at its base. The pin was mounted vertically on an SEM sample vise mount. Cases were air dried and mounted on standard alu- 
minum SEM sample stubs using double stick tape. All samples were coated with approximately $500 \mathrm{~nm}$ of $60 \%-40 \%$ gold-palladium metal in a Kinney vacuum vaporator. Head capsules were examined in a Philips SEM-500 at $3 \mathrm{kV}$ acceleration voltage; cases were examined at 12 $\mathrm{kV}$. Images were recorded on Polaroid Type 55 film.

\section{Description}

Cochliopsyche vazquezae Flint, 1985: 214, figs. 15 , male, female.

Adults. See Flint (1985).

Larva. Head (Figs. 1, 4-7): rounded with large postgenal concavity; frontoclypeal apotome roughly pear shaped; carina extending from anterior margin of head capsule to slightly medial and posterior to eye; areas of reticulation dorsally and laterally; head setal pattern as in Figures $1 \mathrm{~A}, \mathrm{~B}$, with patch of approximately 8-10 closely grouped setae in vicinity of setae 9 and 10 positions, seta 7 closely associated with this group but distinguished from others by its conspicuously longer length, three setae in setal position 16, setae 22 and 23 tentatively identified as such; labrum membranous with three primary dorsal setae; with long, branched, bipectinate setae along anteromesal margin and short to medium length, moderately thick, bipectinate setae along anterolateral margins (Fig. 7); mandibles (Fig. 1C) short, blunt, with short, fine, medial setal brush; left mandible bearing toothed structure situated between two sclerotic flanges; maxillae (Fig. 7) with short, peg-like, apical setae on palps, peg-like and bipectinate setae on galea; labium (Fig. 7) bearing many spatulate, bipectinate setae along dorsal surface; antennae situated close to anterior edge of head capsule, adjacent to frontoclypeal apotome (Fig. 6); head pigmentation golden orange dorsally to light yellow ventrally, posterior half of frontoclypeal apotome darkest; area around eyes pale, light golden to whitish; genae and postgenae light golden. Thorax (Fig. 2A): pronotum well sclerotized, golden to light orange; anterior half covered by long, thin, setae and with eight flat, bladelike setae along each anterolateral edge, as illustrated; mesonotum lightly sclerotized, very pale yellow to clear, with 4550 setae in sa 1 and sa 3 positions, sa 2 with three setae; metanotum largely membranous, setal area sclerites not seen at $195 \times$ magnifi- cation, although they may be present, but ill defined and unpigmented; $s a 1$ and sa 2 each with single seta, sa 3 with six setae; foretrochantin horn-shaped, with a single terminal seta (as in H. borealis, Wiggins 1977, fig. 5.1A); mesoand metathoracic pleural sclerites darkly pigmented with short episternum and long epimeron; legs (Figs. 2B-D) moderately setose, each with very fine setae on trochanter (only visible at higher magnifications); three major, ventral, femoral setae on each leg. Abdomen: lateral hump of segment I with lightly pigmented sclerite similar to that found in Helicopsyche (Wiggins 1977, fig. 5.1A), and bearing single seta; abdominal gills and lateral fringe absent, lateral tubercles present only on abdominal segment VIII; anal proleg setae as illustrated (Fig. 2E); anal claw with prominent tooth and several smaller teeth forming comblike arrangement (Fig. 2E). Length of larvae 5-6 $\mathrm{mm}(n=2)$.

Larval case (Figs. 8, 9). Shaped like a helical snail shell, constructed of sand grains of varying sizes, becoming progressively larger on outer whorls, coiled dextrally in all specimens examined; posterior aperture off center, opening constricted by beveled silken membrane; case dimensions from $1 \times 1.5$ to $2.5 \times 3 \mathrm{~mm}(n=$ 11).

Pupa. Head (Fig. 3A): two pairs long frontal setae, eight pairs setae on labrum, two pairs setae at medial edge of eye near base of antennal scape, one pair setae on scape, ca. 9-13 setae in patch below and mesad of each eye; mandibles long, pointed, with smooth inner margins and each with one pair basolateral setae. Abdomen (Fig. 3B): gills, lateral fringe absent; abdominal hook plates on segments III-VI, as illustrated; venter of segment III with brown hourglassshaped pigmentation, venters of IV and V with much lighter pigmentation; two pairs short ventrolateral setae on segments VI and VII, one pair short setae on pleural region of VIII (these setae best seen in ventral view at $195 \times$ magnification); segment IX with pair of dorsolateral protuberances bearing 3-4 fine, short setae; anal processes long, slender, with apices slightly curved laterad, each bearing six long and eight short apical setae. Pupal sieve plate (Fig. 3C), with many small openings radiating in rows from a point slightly off center.

Specimens examined. Costa Rica: Alajuela: Río Pizote, ca. $5 \mathrm{~km} \mathrm{~N}$ Dos Ríos, $10.948^{\circ} \mathrm{N}$, $85.291^{\circ} \mathrm{W}$, 9 March 1986, el. $470 \mathrm{~m}$, Holzenthal 


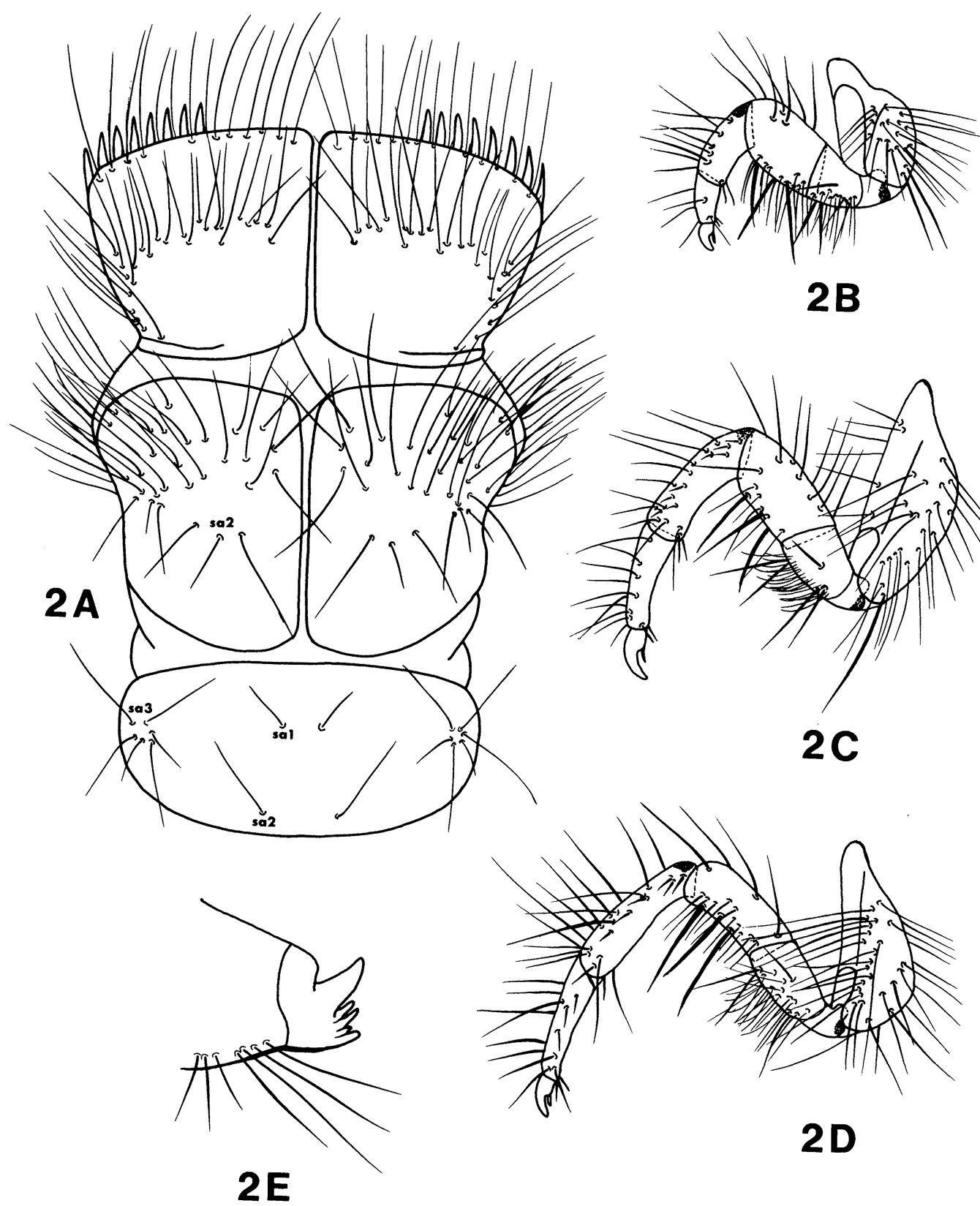

FIG. 2. Cochliopsyche vazquezae Flint, larva: A.-thorax, dorsal; B-D.-left fore, middle, hind legs, respectively, anterior; E.-anal proleg and claw, right lateral.

and Fasth, seven larvae, four pupae, including one female metamorphotype (subsequently lost), numerous adult males and females. All specimens are deposited in the University of Minnesota Insect Collection, St. Paul, Minnesota.

\section{Biology}

Cochliopsyche vazquezae is known from Colombia, Costa Rica, Honduras, and southern Mexico. Cochliopsyche vazquezae adults appeared by the hundreds at ultraviolet lights on the warm, 


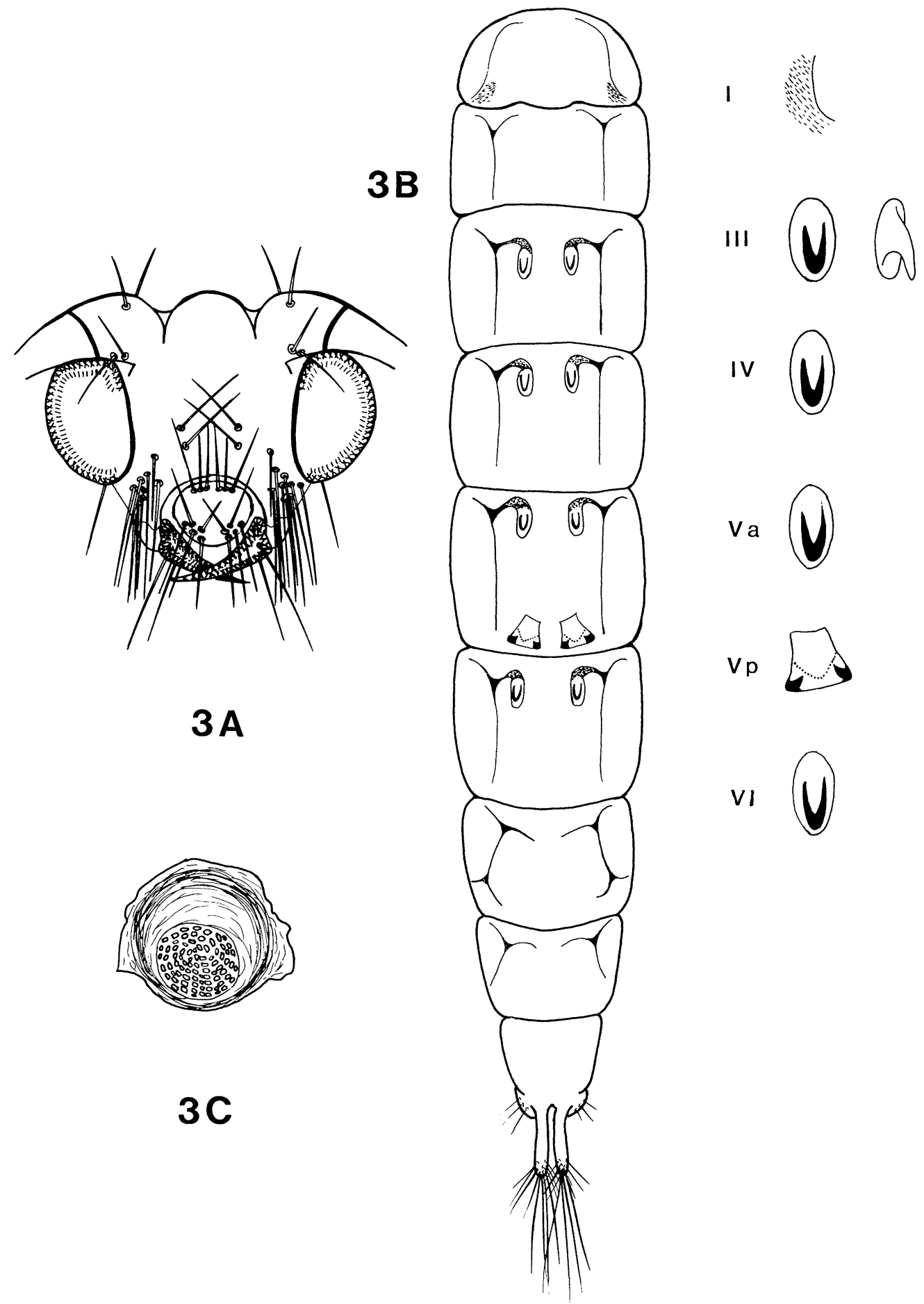

Fig. 3. Cochliopsyche vazquezae Flint, pupa: A.-head, frontal; B.-abdomen, dorsal, hook plates enlarged; C.- - sieve plate. 

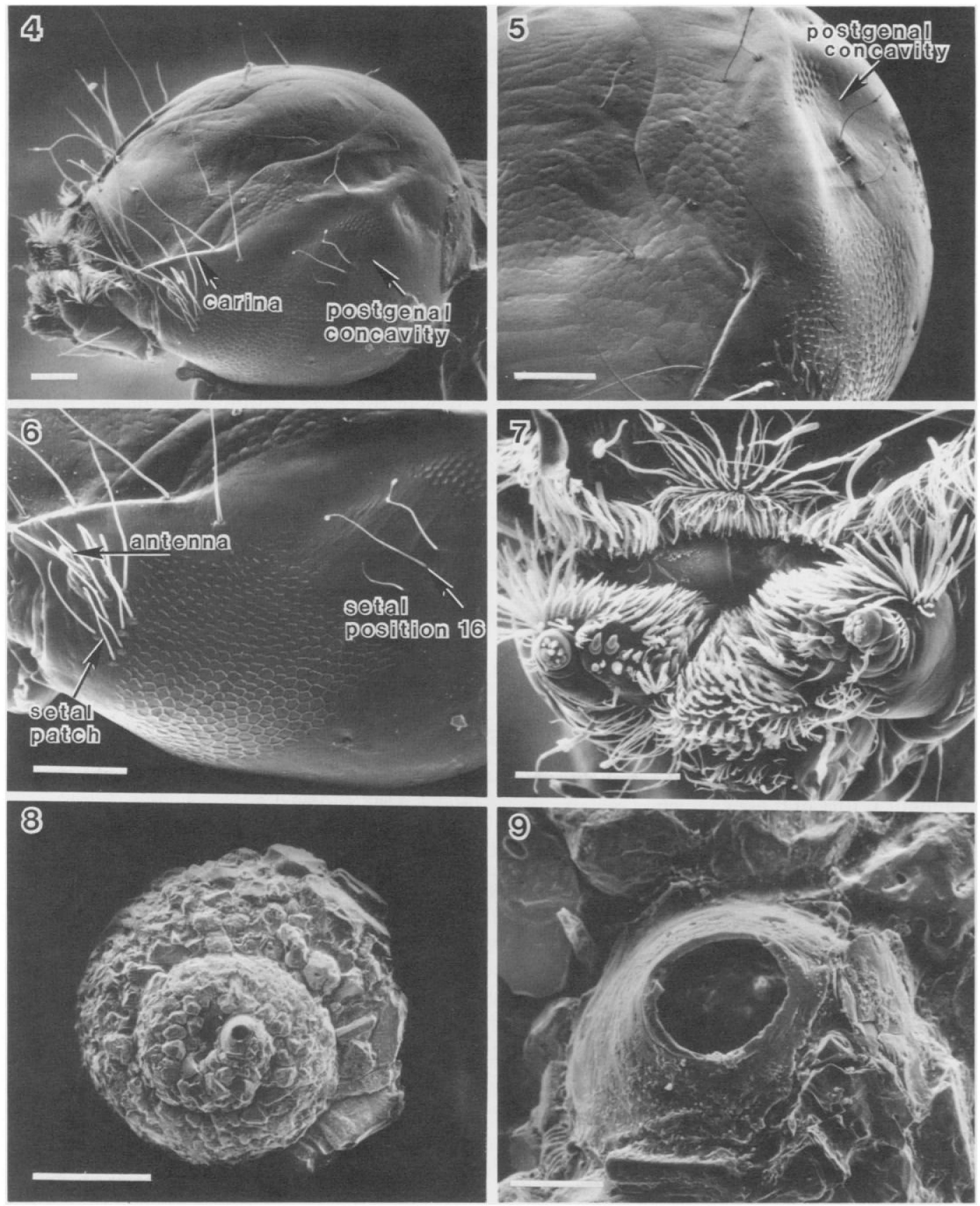

Fics. 4-9. Cochliopsyche vazquezae Flint, larva and case. 4.-Head, dorsolateral; scale $=0.05 \mathrm{~mm}$. 5. -Same, anterodorsal; scale $=0.05 \mathrm{~mm}$. 6.-Same, anterolateral; scale $=0.05 \mathrm{~mm}$. 7.-Mouthparts, anterior; scale = $0.05 \mathrm{~mm}$. 8.-Case, dorsal; scale $=0.5 \mathrm{~mm}$. 9.-Same, posterior opening; scale $0.05 \mathrm{~mm}$. 
humid night of 9 March 1986. Flint (1985) reported that Cochliopsyche adults are generally collected near large streams and rivers. In Costa Rica, larvae and pupae of $C$. vazquezae were collected from sides of large rocks in about $0.75-$ m-deep, moderately flowing, clear, cool water. Not surprisingly, the morphology of the mandibles and associated mouthparts suggest a scraping mode of food gathering. Cases were attached to rocks just above and below the area where the rock was embedded in the surrounding sand substrate. The Rio Pizote at the site collected was up to $10 \mathrm{~m}$ wide in spots with a gentle gradient. Extensive shoals alternated with 1-2-m-deep slack water areas. Rocks and bedrock in shallow, flowing water were covered with dense growths of aquatic macrophytes. Leaf packs were numerous on the upstream faces of rocks, logs, and fallen branches.

\section{Phylogenetic Considerations}

The family Helicopsychidae and its included genera have not been adequately defined based on synapomorphies. Several characters have been used in diagnosing the family (helical larval case, comb-shaped larval anal claw, absence of nigma in wings, hamuli on hindwings, shape and position of setal warts, etc.), but the phylogenetic utility of these characters remains uninvestigated. Discovery of the immature stages of Cochliopsyche allows us to present the following possible synapomorphies for defining the genus (plesiomorphic characters in parentheses):

1. patch of $8-10$ setae in vicinity of head setae 9 and 10 positions (single seta each at positions 9 and 10).

2. large postgenal concavity (no concavity).

3. antennal position at anterior edge of head capsule, adjacent to frontoclypeal apotome (antenna midway between eye and anterior edge of head capsule).

4. three setae in vicinity of head seta 16 position (single seta at position 16).

In addition, two diagnostic adult characters listed by Flint (1985) may be synapomorphic:

5 . antennae thin, 2-3× as long as forewing (antennae thicker, shorter, no longer than forewing).
6. hind tibiae without subapical spurs (hind tibiae with pair of subapical spurs).

These synapomorphies suggest that Cochliopsyche is a monophyletic taxon within Helicopsychidae. However, the phylogenetic generality of these characters is presented with caution since our hypotheses are based on Cochliopsyche immatures of a single species. Also, the phylogenetic relationships among the three helicopsychid genera remain unresolved. In fact, the possibility exists that Cochliopsyche is a monophyletic unit within Helicopsyche, and that the latter genus is paraphyletic. For example, Flint (1968) described a posterolateral indentation in the head capsule of $H$. cubana, which may be homologous to the postgenal concavity we describe for $C$. vazquezae. The absence of a clear definition of the large, morphologically and ecologically diverse genus Helicopsyche presents a major obstacle to the understanding of helicopsychid evolution and classification.

\section{Acknowledgements}

We thank S. W. Hamilton for his helpful information on Helicopsyche larvae and O.S. Flint, Jr., for his insights on helicopsychid evolution and his interest in this project. We also thank W. P. Fasth for his assistance in collecting specimens. This material is based upon work supported by the National Science Foundation Grant BSR-8512368. Paper No. 15,825, Scientific Journal Series, Minnesota Agricultural Experiment Station, St. Paul, Minnesota.

\section{Literature Cited}

BETTEN, C. 1934. The caddis flies or Trichoptera of New York State. New York State Museum Bulletin 292.

BotosANEANU, L., AND J. SYKORA. 1973. Sur quelques Trichoptères (Insecta:Trichoptera) de Cuba. Résultats des expéditions biospeologiques cubanoroumaines à Cuba 1:381-407.

CoWLEY, D. R. 1978. Studies on the larvae of New Zealand Trichoptera. New Zealand Journal of Zoology 5:639-750.

FISCHER, F. C. J. 1970. Trichopterorum Catalogus, Vol. XI. Nederlandse Entomologische Vereniging, Amsterdam.

Flint, O.S. 1968. The caddisflies of Jamaica. Bulletin of the Institute of Jamaica Science Series 19.

FuINT, O. S. 1972. Studies of Neotropical caddisflies, 
XIV: on a collection from northern Argentina. Proceedings of the Biological Society of Washington 85:223-248.

FLINT, O. S. 1983. Studies of Neotropical caddisflies, XXXIII: new species from austral South America (Trichoptera). Smithsonian Contributions to Zoology 377:1-100.

FLINT, O.S. 1985. Studies of Neotropical caddisflies, XXXVI: the genus Cochliopsyche in Middle America (Trichoptera:Helicopsychidae). Anales del Instituto de Biología Universidad Nacional Autónoma de México 56, Serie Zoología 1:213-216.

MalickY, H. 1973. Part XVI: the Ceylonese Trichoptera. Bulletin of the Fisheries Research Station, Sri Lanka (Ceylon) 24:153-177.

MichaElis, F. B. 1973. The distribution and life history of Rakiura vernale (Trichoptera:Helicopsychidae). Journal of the Royal Society of New Zealand 3:295-304.

MiLne, M. J. 1938. The "metamorphotype method" in Trichoptera. Journal of the New York Entomological Society 46:435-437.

MülLER, F. 1921. Briefe und noch nicht veröffentlichte Abhandlungen aus dem Nachlass 18541897. In A. Möller (editor). Fritz Müller, Werke, Briefe und Leben 2:xvii + 667 pp. Gustav Fischer, Jena.

Neborss, A. 1986. Atlas of Trichoptera of the SW Pacific-Australian region. Junk, The Hague.

ReSh, V. H., G. A. LAMberTI, AND J. R. WoOD. 1984. Biology of the caddisfly Helicopsyche borealis (Ha- gen): a comparison of North American populations. Freshwater Invertebrate Biology 3:172-180.

SCHMID, F. 1958. Trichoptères de Ceylan. Archiv fuer Hydrobiologie 54:1-173.

ULMER, G. 1905. Zur Kenntniss aussereuropäischer Trichopteren. Stettiner Entomologische Zeitung 66:1-119.

VAUGHN, C. C. 1985. Life history of Helicopsyche borealis (Hagen) (Trichoptera:Helicopsychidae) in Oklahoma. American Midland Naturalist 113:7683.

VAUGHN, C. C. 1987. Substratum preference of the caddisfly Helicopsyche borealis (Hagen) (Trichoptera:Helicopsychidae). Hydrobiologia 154:201205.

Wiggins, G. B. 1977. Larvae of the North American caddisfly genera (Trichoptera). University of Toronto Press, Toronto.

Williams, D. D., A. T. ReAD, AND K. A. MoORE. 1983. The biology and zoogeography of Helicopsyche borealis (Trichoptera:Helicopsychidae): a Nearctic representative of a tropical genus. Canadian Journal of Zoology 61:2288-2299.

Williams, N. W., AND G. B. Wiggins. 1981. A proposed setal nomenclature and homology for larval Trichoptera. Pages 421-429 in G. P. Moretti (editor). Proceedings of the 3rd International Symposium on Trichoptera. Junk, The Hague.

Received: 16 February 1988 Accepted: 18 May 1988 